Original Article

\title{
Survival, Growth, Feed Efficiency and Carcass Composition of Rabbitfish, Siganus Rivulatus, Fed Different Dietary Energy and Feeding Levels
}

\author{
Ashraf El-Dakar ${ }^{1}$; Gaber Hassanen ${ }^{1}$; Shymaa Shalaby²; Samir Ghoniem ${ }^{1}$ and Osama \\ Zenhom $^{1}$ \\ ${ }^{1}$ Fish Resources and Aquaculture Department. Faculty of Environmental Agricultural Sciences. Suez Canal \\ University. El-Arish, North Sinai and ${ }^{2}$ National Institute of Oceanography and Fisheries, El-Anfoshy, Alexandria, \\ Egypt
}

\begin{abstract}
A feeding trial was conducted to study the effects of dietary energy level and feeding level or daily energy density (DED) on growth, feed conversion, nutrient retention efficiencies, carcass composition, apparent nutrient digestibility and cost benefit analysis for fingerling of rabbitfish, Siganous rivulatus. Twelve net cages, each with dimensions of $1 \times 1 \times 0.4 \mathrm{~m}$ were stocked with 10 fingerlings $(10 \mathrm{~g} / \mathrm{fish}$ initial weight). The fish were fed three isonutrogenous diets $(25 \% \mathrm{CP})$, with varying three oil supplement (0,5 and 10\%), and digestible energy levels (3882, 4056 and $4360 \mathrm{kcal} / \mathrm{kg} \mathrm{diet)}$, at of 2 and $4 \%$ body weight/day (BW/d), corresponding six daily energy densities based on calorie per $1 \mathrm{~g} \mathrm{BW}$ of fish per day. Fish were fed the experimental diets three times daily, six days a week for 98 days. Fish were weighed every two week intervals and feed amounts were adjusted on the basis of the new fish weight. Final body weight, gain and specific growth level (SGR) were increased with an increase in dietary energy level at $2 \%$ feeding level but no trends were evident at $4 \%$ feeding level. Feed conversion (FCR), protein efficiency ratio (PER), productive protein value (PPV\%) and energy retention (ER\%) were higher when fish were fed at $2 \%$ than $4 \%$ feeding level. Furthermore, increasing daily energy density resulted in an increase in SGR until level of $162.4 \mathrm{cal} / \mathrm{g}$ BW of fish. However the differences in SGR above $155.2 \mathrm{cal} / \mathrm{g}$ BW were not significant $(\mathrm{P}>0.05)$. There are a positive effect between energy density and SGR $\left(y=0.099 x+0.5, r^{2}=0.88\right)$. Fat content of carcass increased by increasing both energy and feeding levels while protein content did not affected.
\end{abstract}

Key Words: Rabbitfish, Siganus rivulatus, Dietary energy, Growth, Digestibility.

Received: 10 March 2009

Accepted: 15 August 2009

Correspondence:

Ashraf El-Dakar

Faculty of Environmental Agricultural Sciences. Suez Canal University. El-Arish, North Sinai Suez Canal Univer.

Phone: 2012226129896

E-mail: adakar90@yahoo.com

Copyright: All rights reserved to Mediterranean Aquaculture and Environment Society (MAES) 


\section{Introduction}

The studies on fish nutrition only began about forty years ago (Robaina and Izquierdo, 2000). Since then, significant advances have been made in all aspects of this subject. The number of farmed aquatic species has also been also dramatically increased. Nutrient requirements for most of the first cultured species have not yet been defined and current recommendations are mostly based on data obtained with few selected species such as rainbow trout and channel catfish (Kaushik, 1995). For this reason, research studies on basic nutrition are needed for any candidate species of interest to aquaculture (Robaina and Izquierdo, 2000).

Rabbitfish hold particular promise for marine aquaculture development by virtue of their herbivorous/omnivorous feeding habits and consequent ability to feed low on the aquatic food chain (Tacon, et al. 1990), their high tolerance to environmental factors, tolerance to rough handing and crowding (Carumbana and Luchavez, 1979), fast growth and possibility to obtain their seeds from the wild or by artificial propagation. The requirements of protein and energy for rabbitfish have been investigated by a number of authors (Soletchnik, 1983; Parazo, 1991; Shalaby, 1998 and Shalabi, et al. 2001) and daily feed amounts (El-Sayed, et al. 1993; El-Dakar, 1999 and El-Meligi, 2003). It has been demonstrated that dietary energy contents affect feed intake. Fish might be able to adjust their digestible energy intake (El-Meligi, 2003). They reported that daily DE intakes per unit body weight by rainbow trout were similar between fish fed low and high-energy diets differing in digestible starch and fat levels.

In rabbitfish, it was found that increasing energy intake through increasing feeding level resulted in an increase of final body weight and growth but not for feed conversion and nutrient efficiency (El-Dakar, 1999). At the same time, dietary protein and energy levels may affect the feeding intake in fish. Daily feed intake may decrease as fish generally have been eaten to meet an energy requirement (McGoogan and
Gatlin, 1999). Researcher (Boujard and Médale, 1994) found that juvenile rainbow trout had lower intake when fed higher energy diets. Knowledge about optimum feeding levels is important not only for promoting good growth and feed efficiency, but also for preventing water quality deterioration as the result of excess feeding and enhancing economic viability of aquaculture processing (Ng, et al. 2000). Studies published on the interaction between daily feed intake and dietary energy levels were scarce. Therefore, the present study sought to determine the effect of different dietary energy and feeding levels to obtain the optimum DED and studied their effects on growth, feed conversion, nutrient retention efficiencies, carcass composition, apparent nutrient digestibility and cost benefit analysis for fingerlings of rabbitfish, Siganous rivulatus.

\section{Materials and Methods}

This work was carried out at the Mariculture Research Center, Faculty of Environmental Agricultural Sciences, Suez Canal University, El-Arish, North-Sinai, Egypt.

\section{Fish and Culture Facility}

Rabbitfish were collected from Mediterranean Sea coast at El-Arish. The fish caught were transported in small plastic bucket $(50 \mathrm{~L}-$ capacity) immediately to a rectangular fiberglass tank filled with fresh seawater. Fish were kept in the tank for one week conditioning period. During this period, dead fish was replaced by a healthy one. After the conditioning period they were sorted according to the weight. The feeding trial was in twelve net cages $(100 \times 100 \times 40 \mathrm{~cm}$; $\mathrm{LxWxH}$ ) placed in a large fiberglass tank using two replicate cages per treatment. Each cage was provided with pieces of lead surrounding the bottom to prevent floating and a wooden frame on the top for support. Ten fingerlings of fish having the same weight $(10 \mathrm{~g} / \mathrm{fish})$ were allotted and randomly distributed into experimental cages. Experimental fish were reared in fresh seawater. Water salinity, temperature, $\mathrm{pH}$, 
dissolved oxygen and photoperiod values were $34 \pm 2 \mathrm{ppt}, 28 \pm 2,8.5 \pm 0.3,7 \mathrm{ppm}$ and 12 hour, respectively. Static water system provided with continuous aeration was used and approximately $35 \%$ of the water was changed every day at $800 \mathrm{~h}$.

\section{Experimental Diets and Feeding}

Fish were fed three experimental diets containing 0,5 and $10 \%$ oil represented to three digestible energy levels of 3882, 4056 and $4360 \mathrm{kcal} / \mathrm{kg}$ diet, respectively at restricted two feeding levels of 2 and $4 \% \mathrm{BW} / \mathrm{d}$, namely L2, M2, H2 and L4, M4, H4, respectively. The nutritional treatments were corresponding to six DED levels, based on calorie per unit body weight per day. Fishmeal and soybean meal were used as protein sources, a mixture of cod liver oil and sunflower oil (1:1 v/v ratio) was used as a lipid source. Wheat milling by-product and corn starch were used as sources of carbohydrate level. The experimental diets were prepared by mixing dry ingredients with water. Then pelleted diet was produced through a meat mincer with a $1.5-\mathrm{mm}$ diameter. The pellets were dried by air and stored at $-20^{\circ} \mathrm{C}$ until use. Ingredient composition of the diets is presented in (Table 1). The feed was divided into three equal parts and fed to the fish at 9.00, 12.00 and $15.00 \mathrm{hrs}$, six days a week. Fish were weighed at two-week intervals and feed amounts were readjusted accordingly. Feeding period of the experiment was 98 days.

The gross energy (GE) contents of the experimental diets and fish samples were calculated by using factors of 5.65, 9.45 and $4.22 \mathrm{kcal} / \mathrm{g}$ of protein, lipid and carbohydrate level, respectively (NRC, 1993). Digestible energy (DE) content was calculated from standard physiological fuel values as 4, 4 and $9 \mathrm{kcal} / \mathrm{g}$ of protein, carbohydrate and lipid, respectively (Garling and Wilson, 1976).

\section{Digestibility Trail}

After 12 weeks of the experiment, fish in each cage were transferred to glass aquarium with dimensions of $70 \times 30 \times 40 \mathrm{~cm}$, under the same culture conditions of the feeding experiment, to determine apparent digestibility coefficient
(ADC) by direct method according to (Lovell, 1989). Fish were fed test diets for two weeks, during this period feces in each tank were collected in petery dishes. Uneaten feed and water were removed and collected feces were homogenized and stored in a plastic bag at $-20^{\circ} \mathrm{C}$ for further analysis.

\section{Samples Collection and Analysis}

Fish samples were taken at the beginning experiment to keep frozen at $-20^{\circ} \mathrm{C}$ for subsequent analysis of body composition. At the end of the experiment, five fish were taken randomly sampled from each cage, killed and dissected. Samples of carcass of each cage were pooled and stored frozen at $-20^{\circ} \mathrm{C}$ for subsequent proximate composition analysis. Fish carcass, feed and collected faces were chemically analyzed according to AOAC (1990).

\section{Statistical Analysis}

The results of the experiment were statistically analyzed using the two-way analysis of variance, fixed-effect model to determine the significant differences among treatment means. All statistical analyses were performed according to (Snedecor and Cochran, 1967) using the m-state C software (MStat-C, 1988), Differences were subjected to Duncan's Multiple Range-Test (Duncan, 1955).

\section{Results}

Surviving, Growth, Feed Utilization and Digestibility

Survival rate among all fish groups was insignificant (Table 1). At the feeding level of $2 \% \mathrm{BW} / \mathrm{d}$, final body weight, gain and SGR increased with increasing energy level (Table 2). However, no significant differences $(\mathrm{P}>0.05)$ were observed in growth parameters among fish groups of M2 and H2, while poor growth rate was obtained with group L2. At the higher feeding level, growth performance of rabbitfish was higher than those found at low feeding level. The maximum weight gain and growth were found with M4 group. However, no significant differences $(\mathrm{P}>0.05)$ were observed between $\mathrm{H} 4$ and L4. There was a significant interaction 
between dietary energy level and feeding level. There is also a positive effect $(\mathrm{y}=0.099 \mathrm{X}+0.5$, $\mathrm{r}^{2}=0.88$ ) between DED and SGR of fish (Figure 1). The optimum DED was found at $162 \mathrm{cal} /$ day/ fish, it could be covered with a diet containing $4056 \mathrm{kcal} \mathrm{DE} / \mathrm{kg}$ at $4 \% \mathrm{BW} / \mathrm{d}$.

Table 1: Ingredient composition and chemical analysis proximate of the experimental diets:

\begin{tabular}{|c|c|c|c|}
\hline \multirow{2}{*}{ Item } & \multicolumn{3}{|c|}{ Diet No. } \\
\hline & 1 & 2 & 3 \\
\hline \multicolumn{4}{|l|}{ Gram per $100 \mathrm{~g}$} \\
\hline Fish meal, herring meal $(72 \% \mathrm{CP})$ & 17.5 & 17.5 & 17.5 \\
\hline Soybean meal ( $48 \% \mathrm{CP})$ & 22 & 22 & 22 \\
\hline Wheat brain & 15 & 15 & 15 \\
\hline Wheat milling by-product & 15 & 15 & 15 \\
\hline Corn starch & 26.5 & 21.5 & 16.5 \\
\hline Cod liver oil & 0 & 2.5 & 5 \\
\hline Sunflower oil & 0 & 2.5 & 5 \\
\hline Vitamin premix $^{1}$ & 2 & 2 & 2 \\
\hline Mineral premix ${ }^{1}$ & 2 & 2 & 2 \\
\hline Total & 100 & 100 & 100 \\
\hline \multicolumn{4}{|c|}{ Proximate analysis (\% on DM basis) } \\
\hline Dry matter & 92.73 & 92.87 & 94.16 \\
\hline Crude protein & 25.04 & 26.35 & 25.39 \\
\hline Ether extract & 6.27 & 10.38 & 15.01 \\
\hline Crude fiber & 1.56 & 1.65 & 1.41 \\
\hline Ash & 9.22 & 9.92 & 8.35 \\
\hline Nitrogen free extract & 57.91 & 51.70 & 49.84 \\
\hline \multicolumn{4}{|l|}{ Calculated energy value } \\
\hline Gross energy & 4451 & 4651 & 4956 \\
\hline Digestible energy & 3882 & 4056 & 4360 \\
\hline $\mathrm{P} / \mathrm{E}$ ratio $\mathrm{mg} \mathrm{CP} / \mathrm{kcal} \mathrm{DE}$ & 64.54 & 64.90 & 58.23 \\
\hline
\end{tabular}

1. Eco Vit, Egyptian Veterinary produces and feed additives Co., Demyatta, Egypt. Each kilogram contains 15000 IU, 15000 IU. $2 \mathrm{mg}, 2.5 \mathrm{mg}, 2 \mathrm{mg}, 10 \mathrm{mg}, 3 \mathrm{mg}, 5 \mathrm{mg}, 2 \mathrm{mg}, 2 \mathrm{mg}$, $5.5 \mathrm{mg}, 200 \mathrm{~g}, 90 \mathrm{~g}, 40 \mathrm{~g}, 2.5 \mathrm{~g}, 48 \mathrm{~g}, 3.6 \mathrm{~g}, 23.5 \mathrm{~g}, 8 \mathrm{~g}, 450 \mathrm{mg}$, $200 \mathrm{mg}$ and $20 \mathrm{mg}$ of vitamin A, vitamin D3, vitamin E, vitamin $\mathrm{B} 2$, vitamin $\mathrm{K} 3$, nicotineamide, vitamin B6, vitamin B12, vitamin B1, folic acid, Ca-d-pantothenate, calcium, phosphate, sodium, copper, magnesium, manganese, zinc, iron, cobalt, iodine, and selenium, respectively.
Feed intake was strongly affected by increasing feeding level from $2 \%$ to $4 \%$ (Table 3 ). Lower feed intake was found with low energy density (L2). However, no significant difference ( $\mathrm{P}>0.05$ ) were found between fish fed medium and high energy levels at $2 \% \mathrm{BW} / \mathrm{d}$. At $4 \% \mathrm{BW} / \mathrm{d}$, feed intake was reduced at higher energy diet (H4). It was clear that, feed, protein and energy intakes were elevated by increasing feeding level (i.e. energy intake was increased with increasing dietary energy levels). But, protein intake affected by feeding level, not by energy level. Feed conversion ratio was improved as dietary energy level increased when fish received $2 \% \mathrm{BW} / \mathrm{d}$ feed. However, the best FCR was found with M4 group, represented 162.4 $\mathrm{cal} / \mathrm{g}$ BW DED (Figure 2). Increasing dietary energy beyond this level resulted in a decline in FCR. Protein efficiency ratio and productive protein values were improved by increasing dietary energy levels but they were reduced by increasing feeding level. Rabbitfish was more efficiently utilize protein when received $2 \%$ $\mathrm{BW} / \mathrm{d}$ than 4\% BW/d. Both PER and PPV\% increased by increasing dietary energy level at low feeding level (Table 3). However, they increased up to medium energy level then leveled off at higher feeding level. The same trend was found for energy retention efficiency. Energy retention increased by increasing DE level and decreased with increasing of feeding level. Data in (Table 4) show that increasing of feeding level resulted in an increase in digestibility of DM, $\mathrm{CP}, \mathrm{EE}$ and NFE. However, apparent nutrient digestibilities were higher at high energy-level than at other dietary energy levels.

\section{Carcass Composition}

No significant differences $(\mathrm{P}>0.0 .5)$ in protein content of all fish groups were observed. However, fat content increased with increasing dietary energy and feeding levels (Table 5). There was an interaction in EE and DM contents by combination of dietary energy and feeding levels. On the other hand, ash content decreased by increasing energy and feeding levels. 


\section{Cost-benefit Analysis}

Cost benefit analysis (Table 6) showed that incidence cost for fish fed $2 \%$ feeding level was lower than those fed 4\% BW/d. At lower feeding level, IC decreased dramatically with increasing of dietary energy levels. However at higher feeding level (4\%) IC improved at medium DE level but it elevated at higher DE level. On contrast profitability level was occurred at high energy diet and lower feeding level considerable high feeding level resulted in lower PI at all DE levels.

Table 2: Effect of dietary energy and feeding levels on growth performance and survival of rabbitfish1:

\begin{tabular}{|c|c|c|c|c|c|c|}
\hline Feeding level & Energy level ${ }^{2}$ & $\begin{array}{c}\text { Initial wt. } \\
\text { g/fish }\end{array}$ & $\begin{array}{c}\text { Final wt. } \\
\text { g/fish }\end{array}$ & $\begin{array}{l}\text { Gain }{ }^{1} \\
\text { g/fish }\end{array}$ & $\begin{array}{c}\text { SGR }^{2} \\
\% / d a y\end{array}$ & Survival \% \\
\hline \multicolumn{7}{|c|}{$2 \%$ Feeding level } \\
\hline Low & L2 & 10.20 & $17.69^{\mathrm{c}}$ & $7.49^{c}$ & $0.56^{\mathrm{d}}$ & 95 \\
\hline Medium & M2 & 10.25 & $21.18^{\mathrm{c}}$ & $10.66^{\mathrm{c}}$ & $0.71^{\mathrm{cd}}$ & 100 \\
\hline High & $\mathrm{H} 2$ & 10.25 & $21.62^{c}$ & $11.37^{\mathrm{c}}$ & $0.76^{\mathrm{c}}$ & 95 \\
\hline \multicolumn{7}{|c|}{ 4\% Feeding level } \\
\hline Low & L4 & 10.21 & $27.23^{\mathrm{b}}$ & $17.02^{\mathrm{b}}$ & $1.00^{\mathrm{b}}$ & 100 \\
\hline Medium & M4 & 10.49 & $34.40^{\mathrm{a}}$ & $23.91^{\mathrm{a}}$ & $1.21^{\mathrm{a}}$ & 100 \\
\hline High & $\mathrm{H} 4$ & 10.32 & $32.09^{\mathrm{a}}$ & $21.77^{\mathrm{a}}$ & $1.16^{\mathrm{b}}$ & 90 \\
\hline \multicolumn{7}{|c|}{ Analysis of variance, $P>F$} \\
\hline Feeding level $\mathrm{I}$ & & & 0.001 & 0.001 & 0.02 & 0.061 \\
\hline Energy level $\mathrm{E}$ & & & 0.021 & 0.01 & 0.048 & 0.048 \\
\hline Interaction $\quad \mathrm{F}$ & & & 0.36 & 0.35 & 0.02 & 0.41 \\
\hline Pooled standard & & 0.03 & 0.49 & 0.50 & 0.02 & 2.81 \\
\hline
\end{tabular}

Values within the same column with different superscripts were significantly different at level of $\mathrm{P}<0.05$.

1. Gain $=($ final weight - initial weight $)$

2. Specific growth level $=100$ (Ln final weight - Ln initial weight $/$ days $)$ 
Table 3: Effect of dietary energy and feeding levels on feed and nutrient intake, feed conversion and nutrient efficiencies of rabbitfish:

\begin{tabular}{|c|c|c|c|c|c|c|c|c|}
\hline \multirow{2}{*}{\multicolumn{2}{|c|}{$\begin{array}{c}\text { Energy/feeding } \\
\text { levels }\end{array}$}} & \multirow[b]{2}{*}{$\begin{array}{l}\text { Feed } \\
\text { g/fish }\end{array}$} & \multirow{2}{*}{$\begin{array}{c}\text { Intakes } \\
\text { Protein } \\
\text { g/fish }\end{array}$} & \multirow[b]{2}{*}{$\begin{array}{l}\text { Energy } \\
\text { kcal/fish }\end{array}$} & \multirow{2}{*}{$\frac{\text { FCR }^{1}}{\mathrm{~g} / \mathrm{g}}$} & \multicolumn{3}{|c|}{ Nutrient utilization } \\
\hline & & & & & & $\begin{array}{c}\mathrm{PER}^{2} \\
\mathrm{~g} / \mathrm{g}\end{array}$ & $\begin{array}{c}\text { PPV }^{3} \\
\%\end{array}$ & $\begin{array}{c}\mathrm{ER}^{4} \\
\%\end{array}$ \\
\hline \multicolumn{9}{|c|}{$2 \%$ Feeding level } \\
\hline Low & L2 & $21.17^{\mathrm{e}}$ & $4.92^{\mathrm{e}}$ & $87^{\mathrm{d}}$ & $2.62^{\mathrm{bc}}$ & $1.52^{\mathrm{bc}}$ & $34.19^{\mathrm{bc}}$ & $14.59^{\mathrm{d}}$ \\
\hline Medium & M2 & $24.60^{\mathrm{d}}$ & $6.02^{\mathrm{d}}$ & $106^{\mathrm{c}}$ & $2.14^{\mathrm{b}}$ & $1.77^{\mathrm{ab}}$ & $42.74^{\mathrm{b}}$ & $24.00^{\mathrm{b}}$ \\
\hline High & $\mathrm{H} 2$ & $24.52^{\mathrm{d}}$ & $5.86^{\mathrm{d}}$ & $115^{\mathrm{c}}$ & $2.03^{\mathrm{a}}$ & $1.94^{\mathrm{ab}}$ & $53.14^{\mathrm{a}}$ & $29.27^{\mathrm{a}}$ \\
\hline \multicolumn{9}{|c|}{$4 \%$ Feeding level } \\
\hline Low & L4 & $56.80^{\mathrm{c}}$ & $13.90^{\mathrm{c}}$ & $259^{\mathrm{b}}$ & $3.10^{\mathrm{d}}$ & $1.22^{\mathrm{c}}$ & $28.80^{\mathrm{d}}$ & $14.67^{\mathrm{d}}$ \\
\hline Medium & M4 & $64.92^{\mathrm{a}}$ & $15.89^{\mathrm{a}}$ & $280^{\mathrm{a}}$ & $2.52^{\mathrm{bc}}$ & $1.50^{\mathrm{bc}}$ & $32.12^{\mathrm{cd}}$ & $18.97^{\mathrm{c}}$ \\
\hline High & $\mathrm{H} 4$ & $61.47^{\mathrm{b}}$ & $14.70^{\mathrm{b}}$ & $287^{\mathrm{a}}$ & $2.66^{\mathrm{cd}}$ & $1.48^{\mathrm{bc}}$ & $27.55^{\mathrm{d}}$ & $17.31^{\mathrm{cd}}$ \\
\hline \multicolumn{9}{|c|}{ Analysis of variance, $P>F$} \\
\hline Feeding level & $\mathrm{F}$ & 0.001 & 0.001 & 0.001 & 0.014 & 0.012 & 0.0006 & 0.001 \\
\hline Energy level & $\mathrm{E}$ & -- & 0.003 & 0.001 & 0.036 & 0.06 & 0.04 & 0.008 \\
\hline Interaction & FxE & 0.06 & 0.016 & 0.001 & 0.000 & 0.001 & 0.018 & 0.011 \\
\hline Pooled standar & d error & 0.30 & 0.07 & 1.90 & 0.065 & 0.04 & 1.06 & 0.45 \\
\hline
\end{tabular}

Values within the same column with different superscripts were significantly different at level of $\mathrm{P}<0.05$

1. Feed conversion ratio $=\mathrm{DM}$ intake/weight gain

2. Protein efficiency ratio $=$ weight gain/protein intake

3. Productive protein value $=100($ protein gain/protein intake $)$

4. Energy retention $\%=100$ (gross energy gain/gross energy intake)

Table 4: Effect of dietary energy and feeding levels on apparent nutrient digestabilities 1 of rabbitfish:

\begin{tabular}{|c|c|c|c|c|c|c|}
\hline \multicolumn{7}{|c|}{ Apparent digestibility coefficient ${ }^{1}(\%)$} \\
\hline \multicolumn{2}{|c|}{ Energy/feeding levels } & Dry matter & Crude protein & Ether extract & Crude fiber & $\mathbf{N F E}^{2}$ \\
\hline \multicolumn{7}{|c|}{$2 \%$ Feeding level } \\
\hline Low & $\mathrm{L} 2$ & 74.38 & 92.54 & 85.94 & 40.30 & 57.79 \\
\hline Medium & M2 & 69.51 & 91.45 & 81.56 & 36.84 & 64.89 \\
\hline High & $\mathrm{H} 2$ & 87.95 & 95.61 & 90.65 & 48.84 & 82.93 \\
\hline \multicolumn{7}{|c|}{$4 \%$ Feeding level } \\
\hline Low & L4 & 89.52 & 96.86 & 88.17 & 42.11 & 75.09 \\
\hline Medium & M4 & 86.00 & 94.46 & 90.71 & 46.81 & 79.88 \\
\hline High & $\mathrm{H} 4$ & 86.74 & 89.29 & 87.15 & 42.59 & 85.19 \\
\hline
\end{tabular}

Values within the same column with different superscripts were significantly different at level of $\mathrm{P}>0.05$

1. $\mathrm{ADC}=100$ (nutrient intake - nutrient in feces)/nutrient intake

2. Nitrogen free extract 
El-Dakar et al.

Table 5: Effect of dietary energy ${ }^{1}$ and feeding levels on carcass composition of rabbitfish ${ }^{2}$ :

\begin{tabular}{|c|c|c|c|c|c|}
\hline \multicolumn{2}{|c|}{ Energy/feeding levels } & \multirow{2}{*}{$\begin{array}{c}\text { Dry matter \% } \\
27.75\end{array}$} & \multirow{2}{*}{$\begin{array}{c}\text { Crude protein } \\
49.22\end{array}$} & \multirow{2}{*}{$\begin{array}{c}\text { Crude lipid } \\
28.40\end{array}$} & \multirow{2}{*}{$\begin{array}{l}\text { Ash } \\
21.8\end{array}$} \\
\hline Initial fish & & & & & \\
\hline \multicolumn{6}{|l|}{$2 \%$ Feeding level } \\
\hline Low & L2 & $30.44^{\mathrm{e}}$ & $57.18^{\mathrm{a}}$ & $21.41^{\mathrm{e}}$ & $21.04^{\mathrm{a}}$ \\
\hline Medium & M2 & $35.44^{\mathrm{bc}}$ & $53.46^{\mathrm{a}}$ & $26.61 \mathrm{c}$ & $19.73^{b}$ \\
\hline High & $\mathrm{H} 2$ & $39.30^{\mathrm{a}}$ & $53.10^{\mathrm{a}}$ & $29.32^{\mathrm{b}}$ & $17.43^{\mathrm{c}}$ \\
\hline \multicolumn{6}{|l|}{ 4\% Feeding level } \\
\hline Low & L4 & $33.29^{\mathrm{d}}$ & $57.36^{\mathrm{a}}$ & $23.95^{\mathrm{d}}$ & $18.73^{\circ}$ \\
\hline Medium & M4 & $34.60^{c}$ & $54.90^{\mathrm{a}}$ & $28.67^{\mathrm{b}}$ & $16.41^{\mathrm{d}}$ \\
\hline High & $\mathrm{H} 4$ & $34.47^{\mathrm{c}}$ & $49.33^{\mathrm{a}}$ & $32.91^{\mathrm{a}}$ & $17.76^{\mathrm{c}}$ \\
\hline \multicolumn{6}{|c|}{ Analysis of variance, $\mathrm{P}>\mathrm{F}$} \\
\hline Feeding level $\mathrm{F}$ & & 0.001 & 0.19 & 0.001 & 0.001 \\
\hline Energy level E & & 0.001 & 0.24 & 0.001 & 0.001 \\
\hline Interaction $\quad F x E$ & & 0.001 & 0.31 & 0.025 & 0.001 \\
\hline Pooled standard error & & 0.035 & 0.80 & 0.078 & 0.027 \\
\hline
\end{tabular}

1. L, M and $\mathrm{H}$ diets containing digestible energy of 3882, 4056 and $4360 \mathrm{kcal} / \mathrm{kg}$, respectively and the number below refer to feeding level.

2. Values within the same column with different superscripts were significantly different at level of $\mathrm{P}>0.05$.

Table 6: Effect of dietary energy and feeding levels on costbenefit analysis of rabbitfish:

\begin{tabular}{rccc}
\hline $\begin{array}{c}\text { Feeding } \\
\text { level }\end{array}$ & $\begin{array}{c}\text { Energy } \\
\text { level }\end{array}$ & $\begin{array}{c}\text { Incidence } \\
\text { cost }^{\mathbf{1}}\end{array}$ & $\begin{array}{c}\text { Profit } \\
\text { index }^{2}\end{array}$ \\
\hline $\mathbf{2 \%}$ feeding level & & \\
\hline Low & 3.43 & 2.06 \\
Medium & 2.91 & 2.42 \\
High & 2.81 & 2.50 \\
\hline $\mathbf{2 \%}$ feeding level & & \\
\hline \multicolumn{4}{r}{ Low } \\
Medium & 4.02 & 1.75 \\
High & 3.42 & 2.06 \\
\hline
\end{tabular}

1. Incidence cost $=$ feed cost to produce $1 \mathrm{~kg}$ weight gain fish. 2. Profit index $=$ value of fish/cost of feed consumed, $1 \mathrm{~kg}$ fresh fish equals 6 Egyptian pound (1LE=0.18 US\$)

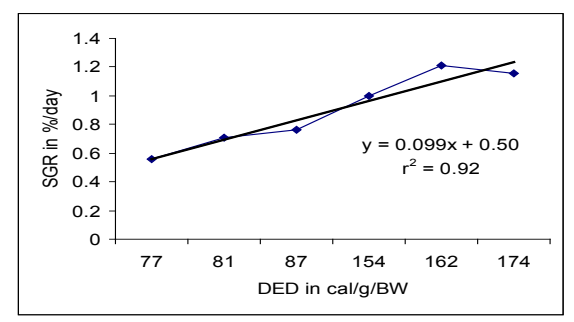

Fig. 1: Relationship between DED and SGR.

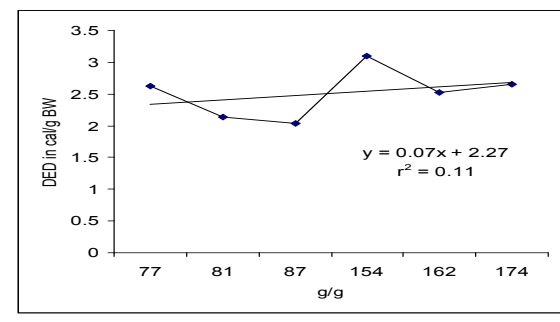

Fig. 2: Relationship between DED and FCR.

\section{Discussion:}

Results indicated that increasing feeding level from 2 to $4 \% \mathrm{BW} / \mathrm{d}$ resulted in a significant increase $(\mathrm{P}<0.05)$ in final body weight, gain and SGR. However, PER, PPV and ER\% decreased as feeding level increased. These results are in agreement with those obtained by researchers EL-Sayed et al. (1993); El-Dakar (1999); ElMeligi (2003); Yufera et al. (1995); El-Sayed (2002) and Abdelghany and Ahmad (2002). Body weight and SGR were proportional to the level of digestible energy offered. However, growth of fish received 4\% improved significantly with increasing DE levels up to 
$4056 \mathrm{kcal} / \mathrm{kg}$ (medium level) and leveled off with further increase in energy levels. From previous studies, growth and feed efficiency of rabbitfish were affected by dietary energy (Parazo, 1991; Shalaby, 1998; Shalabi, et al. 2001 and Parazoa, 1990). The scientist Soletchnik (1983) recommended that feeds for optimum growth of rabbitfish fry should contain total energy about $3700 \mathrm{kcal} / \mathrm{kg} \mathrm{DE}$ in diet of 33\% protein. Findings of Parazoa (1990) showed that growth rate increased with increasing energy levels up to $3832 \mathrm{kcal} / \mathrm{kg} \mathrm{DE}$ in $35 \% \mathrm{CP}$ diet of $S$. guttatas fry. In case of $S$. rivulatus, (Shalaby, 1998) reported that growth performance was not affected by increasing dietary lipids or energy levels. The present study showed the differences among fish fed different energy levels were insignificant $(\mathrm{P}>0.05)$ due to lower activity of lipolytic enzymes (Von Westernhagen and Rosenthal, 1976). Histochemical studies on the intestinal bulb of rabbitfish showed that the variation observed in the activities of digestive enzymes may reflect the feeding habit of $S$. rivulatus. This may have lead to weak lipolytic and moderate level proteolytic energy activities and strong activity of $\beta$-glucuronidase, which is responsible for carbohydrate level digestion (Von Westernhagen and Rosenthal, 1976). Therefore, there was an improvement in ADC of carbohydrate levels with increasing both dietary energy and feeding levels in diets of $S$. rivulatus in the present study. Lower activities of lipid enzymes of $S$. rivulatus, resulted in less utilization of dietary lipids in diets (Lundberg and Lipkin, 1979).

Appetite of fish, as in higher vertebrate levels, appears to controlled by numerous factors. Involvement of brain regulation system via neuropeptides and neurotransitters or feed intake of fish, as in mammals, has been suggested recently (Boujard and Médale, 1994). Feed and protein utilization improved by increasing energy level in diets at lower feeding level however, it declined at higher feeding level. The best FCR, PER and PPV was found at high-energy-diet at $2 \% \mathrm{BW} / \mathrm{d}$. Increasing feed level resulted in an increase of energy lost in the feces as a proportion of the energy intake.
It may be decrease the efficiency of digestion and absorption. Therefore, not all feed intake converted to growth by fish. Study of ElDakar (1999) showed that FCR, PER and PPV improved by decreasing feeding level. In other words, increasing energy density does not seem to be ensuring that requirements for maximal growth are met (McGoogan and Gatlin, 2000). The present study confirmed the above findings. Additionally, the lowest dietary energy levels were not high enough to support high growth levels and should be avoided (Shalaby, 1998). Improve growth and feed efficiency of red drum fed diets with increasing protein and energy density was occurred (Jirsa, et al. 1997). Increasing feeding level improved growth of O. niloticus but reduced FCR, PER, PPV and relative amount of metabolic energy due to increase of feed passage level through the digestive tract leading to depressed digestibility of gross energy (Meyer-Burgdorff, et al. 1989).

Carcass composition of rabbitfish was affected by energy and feeding levels showing in an increase in dry matter, protein, fat and energy contents and a decrease in ash content for carcass composition with increasing energy level. Except protein content of fish fed higher feeding level that was insignificant. In this connection, increasing dietary energy as lipids has shown to increase fat deposition in different species (Shearer, et al. 1997 and Koskela, et al. 1998). There has been evidence to demonstrate level a reduction of fat deposition when dietary energy levels reach a certain point which results in reduced consumption given that fish tend to eat to meet their energy need (McGoogan and Gatlin, 1999 and NRC, 1993). The cost-benefit analysis reveled that fish fed high-energy diet at $2 \% \mathrm{BW} / \mathrm{d}$ was superior to other test diets. However, increasing energy level cased a reduction of incidence cost and an increase of profit index for fish fed lower feeding level.

\section{References}

AOAC 1990. Official methods of analysis of the Association of Official Analytical Chemists. 15th ed. Association of Official Analytical Chemists, Washington, DC. 
Abdelghany, A.E. \& Ahmad, M.H. 2002. Effects of feeding rates on growth and production of Nile tilapia, common carp and silver carp polycultured in fertilized ponds. Aquaculture Research. 33 (6), pp. 415-423.

Boujard, T. \& Médale, F. 1994. Regulation of voluntary feed intake in juvenile rainbow trout fed by hand or by selffeeders with diets containing two different protein/energy ratios. Aquatic Living Resources. 7, pp. 211-215.

Carumbana, E.E. \& Luchavez, J.A. 1979. A comparative study of the growth rates of Siganus canaliculatus, S. spinus and S. guttatus reared under laboratory and seminatural conditions in Southern Negros Oriental, Philippines. Silliman Journal. 26 (2\&3), pp. 187-209.

Duncan, D.B. 1955. Multiple range and multiple F-test. Biometrics. 11, pp. 1-42.

El-Dakar, A.Y. 1999. Effect of different feeding levels on performance of rabbitfish, Siganus revulatus, fingerlings. Egyptian Journal Aquatic Biology and Fisheries. 3 (4), pp. 35-54.

El-Meligi, U.A.Z.E. 2003. Studies on production of marine fish in North Sinai. M.Sc., Faculty of Environmental Agricultural Sciences, Suez-Canal University.

El-Sayed, A.F.M., Mostafa, K.A., Mohammadi, J.S., Dohaimi, A.A. \& Kayid, M. 1993. Intensive culture of rabbitfish in Qatar: Effects of stocking density and feeding level on growth rates and feed utilization of Siganus canaliculatus. Proceeding of the First International Symposium on Aquaculture Technology and Investment Opportunities. Ministry of Agriculture and Water, Riyadh, Saudi Arabia, pp. 109-117.

El-Sayed, A.F.M. 2002. Effects of stocking density and feeding levels on growth and feed efficiency of Nile tilapia (Oreochromis niloticus L.) fry. Aquaculture Research. 33 (8), pp. 621-626.

Garling Jr., D.L. \& Wilson, R.P. 1976. Optimum dietary protein to energy ratio for channel catfish fingerlings, Ictalurus punctatus. Journal of Nutrition. 106 (9), pp. 1368-1375.
Jirsa, D.O., Davis, D.A. \& Arnold, C.R. 1997. Effects of dietary nutrient density on water quality and growth of red drum Sciaenops ocellatus in closed systems. Journal of the World Aquaculture Society. 28 (1), pp. 68-78.

Kaushik, S.J. 1995. Implications of biotechnology for fish nutrition, production and health. Journal of Marine Biotechnology. 3 (1-3), pp. 46-49.

Koskela, J., Jobling, M. \& Savolainen, R. 1998. Influence of dietary fat level on feed intake, growth and fat deposition in the whitefish Coregonus lavaretus. Aquaculture International. 6 (2), pp. 95-102.

Lovell, T. 1989. Nutrition and feeding of fish. Van Nostrand Reinhold, New York.

Lundberg, B. \& Lipkin, Y. 1979. Natural food of the herbivorous rabbitfish (Siganus spp.) in the Northern Red Sea. Botanica Marina. 22, pp. 173-181.

McGoogan, B.B. \& Gatlin III, D.M. 1999. Dietary manipulations affecting growth and nitrogenous waste production of red drum, Sciaenops ocellatus. I. Effects of dietary protein and energy levels. Aquaculture. 178 (3-4), pp. 333-348.

McGoogan, B.B. \& Gatlin III, D.M. 2000. Dietary manipulations affecting growth and nitrogenous waste production of red drum, Sciaenops ocellatus. II. Effects of energy level and nutrient density at various feeding rates. Aquaculture. 182 (3-4), pp. 271-285.

Meyer-Burgdorff, K.H., Osman, M.F. \& Günther, K.D. 1989. Energy metabolism in Oreochromis niloticus. Aquaculture. 79 (1-4), pp. 283-291.

MStat-C 1988. MStat director. Crop and Soil Science Department, Michigan State University, East Lansing, MI, USA.

National Research Council 1993. Nutrient requirements of fish. National Academy Press, Washington, D.C. 
Ng, W.K., Lu, K.S., Hashim, R. \& Ali, A.B. 2000. Effects of feeding rate on growth, feed utilization and body composition of a tropical bagrid catfish. Aquaculture International. 8, pp. 19-29.

Parazoa, M.M. 1990. Effect of dietary protein and energy level on growth, protein utilization and carcass composition of rabbitfish, Siganus guttatus. Aquaculture. 86 (1), pp. 41-49.

Parazo, M.M. 1991. An artificial diet for larval rabbitfish Siganus guttatus Bloch. in Fish nutrition research in Asia, ed. S.S. De Silva, Asian Fisheries Society, Manila, Philippines, pp. 43-48.

Robaina, L. \& Izquierdo, M. 2000. Methodological strategies for the determination of nutrient requirements in finfish. Cahiers Options Méditerranéennes. 47, pp. 25-41.

Shalabi, S.M., El-Daker, A.Y. \& Ghunaim, S.E. 2001. Protein-sparing effect by carbohydrate in diets of rabbitfish, Siganus rivulatus. Egyptian Journal of Aquatic Biology \& Fisheries. 5 (4), pp. 87-98.

Shalaby, S.M. 1998. Nutrition requirements of rabbitfish, Siganus rivulatus, fingerlings. $\mathrm{PhD}$, Alexandria University, Egypt.
Shearer, K.D., Silverstein, J.T. \& Plisetskaya, E.M. 1997. Role of adiposity in food intake control of juvenile chinook salmon (Oncorhynchus tshawytscha). Comparative Biochemistry and Physiology - A Physiology. 118 (4), pp. 1209-1215.

Snedecor, G.W. \& Cochran, W.G. 1967. Statistical methods. 6th ed. Iowa State University Press, Ames, Iowa, USA.

Soletchnik, P. 1983. Aspects of nutrition and reproduction in Siganus guttatus, with emphasis on applications to aquaculture. SEAFDEC Aquaculture Department.

Tacon, A.G.J., Rausin, N., Kadari, M. \& Cornelis, P. 1990. The food and feeding of marine finfish in floating net cages at the National Seafarming Development Centre, Lampung, Indonesia: Rabbitfish, Siganus canaliculatus (Park). Aquaculture Research. 21 (4), pp. 375-390.

Von Westernhagen, H. \& Rosenthal, H. 1976. Some aspects of the suitability of various Philippine siganid species (Siganidae) for mariculture. Aquaculture. 9 (C), pp. 297-311.

Yufera, M., Fernandez-Diaz, C. \& Pascual, E. 1995. Feeding rates of gilthead seabream (Sparus aurata), larvae on microcapsules. Aquaculture. 134 (3), pp. 257-268. 